\title{
OFD1 and VFL3/CCDC61 in basal body positioning and docking in Paramecium
}

\author{
H Bengueddach*, M Lemullois, J Cohen, AM Tassin, A Aubusson-Fleury, F Koll \\ From Cilia 2014 - Second International Conference \\ Paris, France. 18-21 November 2014
}

\section{Objectives}

Ciliogenesis is conditioned by a correct positioning/ anchoring of the basal body at the cell surface. In Paramecium we have shown that three conserved proteins FOR20, centrin 2 (CEN2) and centrin 3 (CEN3) participates in this process, with FOR20 and CEN2 being also involved in the transition zone assembly. We established a chronology in basal body assembly: CEN2 is required for FOR20 recruitment, the latter being necessary to recruit CEN3. Our goal now is to integrate others molecules in this cascade.

\section{Methods}

We used a combination of electron microscopy, immunocytochemistry, GFP protein tagging and RNAi knockdowns to study the function of OFD1 and VFL3/CCDC61 in Paramecium. OFD1 is a well-studied protein which is involved in human development whose mutations in human males can impair basal body docking. In contrast, only studies in Chlamydomonas indicate that VFL3 could be involved in this phenomenon.

\section{Results}

As in human, the depletion of OFD1 in Paramecium induces defects in basal body docking, these defects being similar to those observed upon inactivation of FOR20, CEN2 and CEN3; 1) like FOR20 and despite its distal location on anchored basal bodies, OFD1 is recruited early during their assembly; 2) while the recruitments of OFD1 and CEN2 proceed independently, the two molecules are required for the recruitment of FOR20. We also present preliminary results indicating that VFL3/CCDC61 is crucial for maintaining both basal body polarity and positioning and for the recruitment of CEN3, but neither for CEN2 or OFD1.

CGM, CNRS, Gif Sur Yvette, France
Published: 13 July 2015

doi:10.1186/2046-2530-4-S1-P29

Cite this article as: Bengueddach et al:: OFD1 and VFL3/CCDC61 in basal body positioning and docking in Paramecium. Cilia 2015 4(Suppl 1):P29.
Submit your next manuscript to BioMed Central and take full advantage of:

- Convenient online submission

- Thorough peer review

- No space constraints or color figure charges

- Immediate publication on acceptance

- Inclusion in PubMed, CAS, Scopus and Google Scholar

- Research which is freely available for redistribution 